\title{
Hypothesis: Relationship of Skin Morphology and Cutaneous Scarless Wound Healing in Sunda Porcupine (Hystrix javanica)
}

\author{
Andhika Y Prawira $^{\text {a) }}$, Supratikno $^{\text {b) }}$, Savitri Novelina ${ }^{\text {c) }}$, Srihadi Agung Priyono ${ }^{\text {d)* }}$ \\ Department of Anatomy Physiology and Pharmacology, Faculty of Veterinary Medicine, \\ Bogor Agricultural University (IPB), Bogor, Indonesia \\ a)andhikayudhaprawira60@gmail.com \\ b) supra_koko@yahoo.com \\ c) savitri.novelina@gmail.com \\ d) corresponding author: ysrihadi@ipb.ac.id
}

\begin{abstract}
Sunda porcupine (Hystrix javanica) is one among the wild mammals of Indonesia. The porcupine skin shows peculiar appearance by the presence of quills, spine like structure, instead of hair, that commonly found in mammals. On the other hand, our previous preeliminary study observed a relatively quick process in wound healing with no scar in the skin of sunda porcupine. In the present study, we noted that quill follicles appeared as dominant structure in the skin. The quill follicles were larger and showed complex structure when compared to that of the hair follicles. The quill follicles in the porcupine were consisted of high density of connective tissue and rich in fibroblast, a lot of keratinocytes lined the canal and around the follicles; a plenty amount of adipose / fat tissue, a well-developed arrestor muscles and sebaceous glands. One of the physiologic events present in the skin is wound healing process. Wound healing is a complex process in which many substances in the skin, such as blood vessel, connective tissue, leukocyte, cytokines and chemokines are involved. The hair follicles which are the main appendages of the mammalian skin has important roles in wound healing process, in some ways, such as source of the keratinocytes and fibroblast in closuring and repairing wound site; the hair cycle has implication to skin immune system; and modulation of the extracellular matrix around the hair follicles through cell-cell and cell-matrix interaction. The physiologic process in the skin that related to hair follicles should be also existed in quill follicles with considerably implication due to the size and complexity of the quill follicle structure. We suggest that scarless wound healing process in the porcupine skin might be closely related with the structure and function of the quill follicles
\end{abstract}

Keywords: sunda porcupine, skin, quill follicle, hair, wound healing

\section{INTRODUCTION}

The skin is the largest organ of the body and responsible as physical barrier of the body. Many of disruptions occur to the skin at any time. Generally the healing process will be resulting in scar formation. Our pre-eliminary study in sunda porcupine (Hystrix javanica) showed the cutaneous wound healing process occured relatively quick without scar formation. Sunda porcupine is one among the wild mammals of Indonesia. The porcupine 
skin shows peculiar appearance by the presence of quills, spine like structure, instead of hair, that commonly found in mammals. In present study, we found several morphological characteristic in sunda procupine' skin both macroscopic and microscopic level. This paper will try to corelate the sunda procupine's skin structure and its scarrless wound healing process compared to the common wound healing theories involving several components in skin that function in the process.

\section{SUNDA PORCUPINE SKIN MORPHOLOGY}

In common mammals, the hairs are the main appendages that cover almost body surface. In contrast to common mammal, sunda porcupine have the quill as the main appendage in its skin that fill almost the part of the dermis. The quill follicles of sunda porcupine are obviously larger and complex than hair follicle.

The skin of the sunda porcupine is covered mostly by spine-like structrue, called quill. The quill distribution is vary in size and shape found in entire body of the porcupine. The quill can be differentiated into 4 types (spine, true quill, transtitional quill, and rattle quill). The skin of sunda porcupine in dorsal region have likely similar characteristic, which is loose, scaly and wrinkled texture due to presence of quill clusters which contain several quills. Hairs only grow near the orifices of the quill follicle.

Topographic observation reveal the inner structure of sunda porcupine skin. The quill follicle is the dominant property in the skin. It is bullet shaped that project from the epidermis to the subcutaneous muscle. Quill follicle is composed by high density of collagen network in follicle sheat, plenty amount of adipose tissue, a large and developed sebaceous gland and $\mathrm{m}$. arrector. The connective tissue in proximal part of the quill follicle project to the quill canal and form the lobules which filled by adipose tissue. Among the fat tissue, the sebaceous glands are found in the proximal part of quill follicle. Inner wall of quill follicle is consisted of loose collagen fibers compare to the sheat. In addition, the lumen of the quill follicle canal is lined by epidermal epithelium.

The amount of adipose tissues in quill follicle are obviously found in distal part. The growing quill are embedded in this adipose tissue in distal part. The middle part of quill follicle are surrounded by a well developed $\mathrm{m}$. arrector pili that prolonged to the caudal part of the quill. The sebaceous gland of the skin of porcupine is remarkably larger and developed than common gland in mammals. 

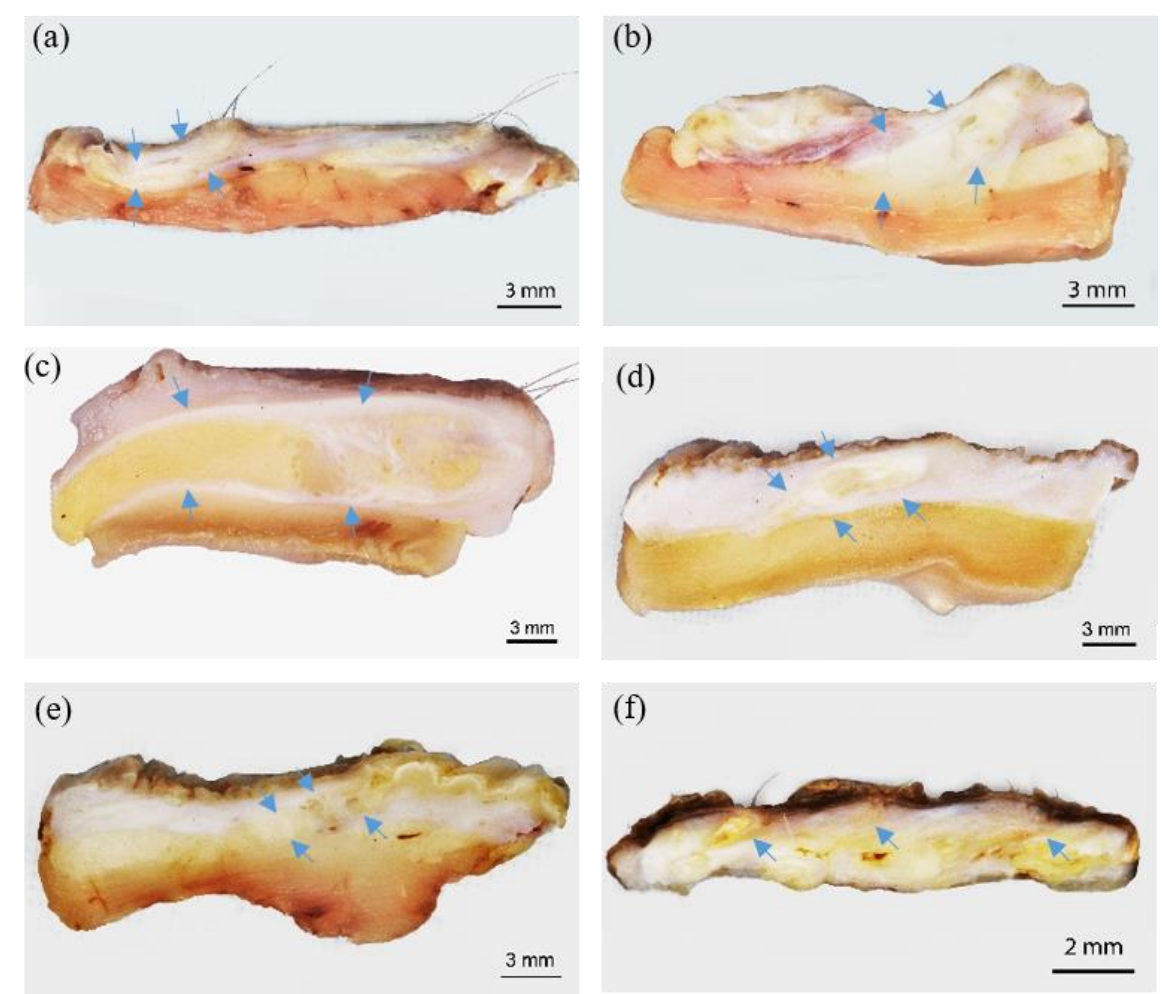

Figure 1. The cross section of sunda porcupine's skin show quill follicle (blue arrows) fill almost the dermis of skin in dorsal region of the body, (a) thorax dorsal, (b) thoracolumbar, (c) lumbardorsal, (d) lumbosacral, (e) radix caudal, (f) apex caudal.

\section{CUTANEOUS WOUND HEALING}

Cuteneous wound healing is the complex process involving many mediators, matrix extracelluler, skin cells, and leukocytes which contrbure in three main steps. The steps are hemostatic and inflamation; formation of granular tissue (migration and proliferation); and remodelling (maturation) [1]. Almost the damage of the skin will healed in relative quick of time and eficien in several weeks, but forming the scar which non estheticaly and not perfectly functional. The connective tissue complex formed in the scar has different formation compared to normal tissue in the skin [2].

In cutaneous wound healing, cytokine has an important role to many process in tissue. The three main phases of the wound healing have a role cytokine charateristic which can modulate scar tissue formation, such as interleukin-10 (IL-10), Interleukin-6, Vascular Endothelial Growth Factor (VEGF), and Transformation Growth Factor (TGF). Interleukin10 has important role to reduce the inflamation respon. In addition, IL-10 can induce the production and formation of reticular fibers in dermis layer of the skin which can be used to reduce the scarr tissue in skin ([3],[4]). Interlukin-6 is one of the cytokine that has important role in induce inflamatory respone by increase the infiltration of neutrophils and macrophages to the wound site; inisiate the angiogenesis and collagen deposition [5].The regulation of IL-6 and IL-10 production affect the formation of the scar tissue.

One of the cytokine that has role in the formation of scar tissue is vascular endothelial growth factor (VEGF). This cytokine initiate the formation of blood vessels in granular tissue. Many blood vessels in granular tissues will initiate the migration of fibroblasts to 
increase production of connective tissue at the wound site ([6],[7]). TGF- $\beta$ has role in regulate deposition of extracellular matrix and migrating of cells in the matrix. TGF- $\beta$ induces fibronectin, chondroitin / dermatin sulfate, proteoglican, collagen, and glicosaminoglican production. TGF- $\beta$ can increase the rate of wound healing and induces tissue granulation [8]. The decrease of TGF- $\beta 1$ and VEGF cause a decrease in collagen accumulation and the process of angiogenesis [5].

One mammals known have the capability to enclosure the deep wound with no scar formation is spiny mice (Acomys sp) in Africa. This mammals have the regeneration and scar-free wound healing process in adult individu instead of other adult mammals have no that capability. This capability have corelation to its skin structure, which is weak skin type and the presence of spine-like hair follicles in the skin [9]. That phenomenon of wound healing without scar formation is also observed in sunda procupine (Hystrix javanica). We suggest that this process may be correlated with the structure of the skin of sunda porcupine. The quill follicles are main component in our hypothesis as this structure is the dominant and main component in sunda porcupine's skin. These hypotesis will correlate and compare the common theories of roles of hair follicle physiologic in the skin immune system and wound healing process to the quill follicle structure of sunda porcupine.

Generally the hair follicle have role in wound healing, such as sourch of keratinocyes and fibroblast. The keratinocyte around the hair orificium or infundibulum contribute to the reepithelization in wound site. The keratinocyte will regenerate and migrate to the wound site resulting in thick epidermis around the margin of wound site. In addition the cells forming the connective tissue in hair follicle, the fibroblast and fibrocyte, have role in deposisition of collagen in dermal damage and differentiate into dermal papilla of new hair follicle ([10], [11], [12], [13]). If the structure of the hair follicles are compared to the quill follicles, the structure of quill follicles are more complex and bigger. This differences contribute to the mount of keratinocyte and fibroblast in the follicles resulting in the potential of these cells to proliferate and migrate to wound site are better than the hair follicles did to repair the damage.

The hair follicle in anagen stage has the implication in immune system in skin. The anagen stage make the fluctuation in some immune properties in skin such as intrafollicular Langerhans cells, $\gamma / \delta$-TCR + , lymphocytes, and perifollicular macrophages [14]. The immplication of this fluctuation usually suppressed the skin immune respone in all part of the body [15]. The immunosupressive agent found in this phenomenon such as ACTH, $\alpha-$ MSH, TGF $\beta$ 1, and IL-10 ([15], [16], [17]). We assumed that this physiologic event is exist well in porcupine skin. The latter is due to the characteristic of the skin which had quill as the main derivat. The needs of cell proliferation to form the whole quill in anagen stage should be give the considerable feedback in immune system supression of the sunda porcupine skin. We suggest that these implications had role in scarless healed skin in sunda procupine, as the some the immune supression agent, such as IL-10 and TGF $\beta-1$, had role in the well repaired scarless tissue.

The quill follicle sheat is composed by high density of connective tissue of collagen fiber and other components. This network of fiber is denser than reticular fiber in the dermis. The type of collagen might be correlated in formation of this network. One of the main component in wound healing is the role of the connective tissue or extracellular matrix in the modulate the migration and proliferation of many cells to the wound site by the interaction of cell to cell and cell to matrix [18]. Some parts on of these molecules may bind, activate or inhibit the activity of cytokines and influence the behavior of cells by direct contact. The 
composition of connective tissue is very important in the regulation of biological functions of a tissue [1]. Regulation of matrix extracellular deposisiton is a key of many physiological and pathological processes. It was necessary in the process of wound healing which is characterized by ECM molecules to be synthesized rapidly during the process of granular tissue formation and the replacement process by the mature fibers. Synthesis process will be occured simulaneously with degradation during the process to produce normal and functional tissue. Various cytokines and growth factors play a role in this regulatory process such as transforming growth factor (TGF) $-\beta$, interleukins, tumor necrosis factor (TNF), plateletderived growth factor (PDGF) and other compounds [19].

\section{CONCLUSION}

We suggest that scarless wound healing process in the porcupine skin might be closely related with the structure and function of the quill follicles. This hypothesis should provide basic information to investigate more about the physiologic of wound healing in sunda porcupine.

\section{References}

1. R. A. F. Clark. Wound repair: overview and general considerations. In: The molecular and cellular basis of wound repair, edited by R.A.F Clark (Plenum Press, New York, 1996) pp. 3-50.

2. G. C. Gurtner, S. Werner, Y. Barrandon, et al., Nature 453, 314-321 (2008)

3. G. P. G. Yang, I. J. I. Lim,T. T. T. Phan, et al., Wound Repair Regen 11, 411-418 (2003)

4. I. Kieran, A. Knock, J. Bush, et al., Wound Repair Regen 21, 428-436 (2013)

5. Z. Q. Lin, T. Kondo, Y. Ishida, et al., Journal of Leukocyte Biology 73, 713-721 (2003)

6. T. R. Kyriakides, J. W. Y. Tam, P. Bornstein, J. Invest. Dermatol 113, 782-787 (1999)

7. P. Laplante, I. Sirois, M. A. Raymond, et al., Cell Death Differ 17, 291-303 (2010)

8. J. M. Cruse andR. E. Lewis, Atlas of Immunology 2nd Edition. (CRC Press LLC, United states of America,2004) pp. 315-316

9. A. W. Seifert, S. G. Kiama, M. G. Seifert, et al., Nature 489, 562-565 (2012)

10. R. F. Oliver, J Embryol Exp Morphol 15, 331-347 (1966)

11. M. Inaba, J. Anthony, C. McKinstry, J Invest Dermatol 72, 224-231 (1979)

12. S. M. Prouty, L. Lawrence, K.S. Stenn, Am J Pathol 148, 1871-1885 (1996)

13. G. Cotsarelis, P. Kaur, D. Dhouailly, et al., Exp Dermatol 8, 80-88 (1999)

14. R. Paus, C. van Der Veen, S. Eichmuller, et al., J Invest Dermatol 111, 7-18 (1998)

15. Y. Tokura, U. Hofmann, S. Muller-Rover, et al., Cell Immunol 178, 172-179 (1997)

16. V.A. Botchkarev, N. V. Botchkareva, P. Welker, et al., FASEB J 13: 395-410 (1999)

17. R. Paus, V. A. Botchkarev, N. V. Botchkareva, et al., Ann NY Acad Sci 885, 350-363 (1999)

18. A. Shock and G. J. Laurent,"Cell adhesion in wound healing and pulmonary fibrosis,"in Lung Biology in Health and Disease. Adhesion Molecules and the Lung, edited by P. A. Wang And Fantone J. C. (Marcel Dekker Inc., New York, 1996) pp. 177-209

19. C. Mauch, T. Oono, B. Eckes, T. Krieg, 1994, "Cytokines and wound healing" in Epidermal Growth Factors and Cytokines., edited by T.A.Luger and Schwarz, T. (Marcel Dekker, New York, 1994) pp. 325-344 